\title{
TPACK Based Open Ended Approach to Improve Mathematical Reasoning Skills
}

\author{
Khori Adelina Fitriani \\ SD Negeri Kemiri 06 \\ khori.adelina@gmail.com
}

\section{Article History}

received $3 / 12 / 2020$

revised 17/12/2020

accepted $31 / 12 / 2020$

\begin{abstract}
Elementary school mathematics learning in Indonesia can be said to be still lacking. During this time, students tend to dislike or even fear mathematics subjects, especially in the context of mathematical reasoning. In the field of education, teachers must be able to develop students' mathematical reasoning by using appropriate strategies. So we need appropriate approaches and media to develop mathematical reasoning abilities. The purpose of this study to explain the concept of an open-ended approach based on TPACK, the concept of mathematical reasoning and the relationship between an open-ended approach based on TPACK and mathematical reasoning. The result of this study are: (1) TPACK-based Open ended Approach is learning that presents a problem that has more than one correct method or solution, which is presented with the help of ICT-based media. (2) Mathematical reasoning is the ability to conclude and prove a statement, and solve problems in mathematics. (3) TPACK-based open ended approach can improve mathematical reasoning.
\end{abstract}

Keywords: mathematical reasoning, open ended approach, TPACK

\begin{abstract}
Abstrak
Pembelajaran matematika Sekolah Dasar di Indonesia dapat dikatakan masih kurang. Peserta didik selama ini cenderung tidak suka atau bahkan takut terhadap mata pelajaran matematika, apalagi dalam konteks penalaran matematis. Di bidang pendidikan guru harus mampu mengembangkan penalaran matematis peserta didik dengan menggunakan strategi yang tepat. Jadi kita membutuhkan pendekatan dan media yang sesuai untuk mengembangkan kemampuan penalaran matematis. Tujuan penelitian ini adalah untuk menjelaskan konsep pendekatan open ended berbasis TPACK, konsep penalaran matematis dan hubungan pendekatan open ended berbasis TPACK dengan penalaran matematis. Hasilnya penelitian ini adalah (1) Pendekatan Open ended berbasis TPACK adalah pembelajaran yang menyajikan suatu permasalahan yang memiliki metode atau penyelesaian yang benar lebih dari satu, yang disajikan dengan berbantuan media yang berbasis TIK. (2) Penalaran matematis adalah kemampuan menyimpulkan dan membuktikan suatu pernyataan, serta menyelesaikan masalahmasalah dalam matematika. (3) Pendekatan open ended berbasis TPACK dapat meningkatkan penalaran matematis.
\end{abstract}

Kata kunci: penalaran matematis, pendekatan open ended, TPACK

Social, Humanities, and Education Studies (SHEs): Conference Series https://jurnal.uns.ac.id/shes

p-ISSN 2620-9284 e-ISSN 2620-9292 


\section{PENDAHULUAN}

Dunia pendidikan tak lepas dari kegiatan belajar dan mengajar. Belajar dan mengajar merupakan dua konsep yang tidak bisa dipisahkan satu sama lain. Pembelajaran merupakan suatu bantuan yang diberikan oleh guru kepada peserta didik di lingkungan belajar dengan tujuan agar peserta didik mendapatkan ilmu pengetahuan, sikap maupun ketrampilan (Anggarayanthi, Suniasih, \& Suara, 2016).

Dalam proses belajar mengajar ada empat komponen penting yang berpengaruh pada hasil belajar peserta didik, yaitu bahan belajar, suasana belajar, media dan sumber belajar, serta guru sebagai subyek pembelajaran. Keempat komponen tersebut sangat penting dalam proses pembelajaran, sehingga sangat membantu dalam tercapainya tujuan belajar yang optimal. Media sebagai salah satu komponen dalam kegiatan belajar mengajar dan sumber belajar yang digunakan dalam pembelajaran dipilih atas dasar tujuan dan bahan pelajaran yang telah ditetapkan, oleh karena itu guru sebagai subyek pembelajaran harus dapat memilih media dan sumber belajar yang tepat, sehingga bahan pelajaran yang disampaikan dapat diterima peserta didik dengan baik (Anas, 2016:29).

Pembelajaran matematika di Sekolah Dasar Indonesia dapat dikatakan masih kurang, terbukti dari hasil penelitian tim Programme of International Student Assesment (PISA) tahun 2009. Sekitar sepertiga peserta didik di Indonesia hanya bisa mengerjakan soal jika pertanyaan dan soal kontekstual diberikan secara eksplisit serta semua data yang dibutuhkan untuk mengerjakan diberikan secara tepat Hanya 0,1\% peserta didik Indonesia yang mampu mengembangkan dan mengerjakan pemodelan matematika yang menuntut ketrampilan berpikir dan penalaran (Zubaidah, 2016).

Peserta didik juga selama ini cenderung tidak suka atau bahkan takut terhadap mata pelajaran matematika. Hal ini bukan rahasia lagi, peserta didik sering kali merasa bosan dan menganggap matematika sebagai pelajaran yang tidak menyenangkan. Peserta didik juga mengalami kesulitan dalam belajar matematik, sehingga mengakibatkan hasil belajar matematikanya rendah. Pembelajaran yang dilakukan masih kurang berarti, atau bermakna sehingga penguasaan peserta didik terhadap matematika menjadi kurang baik.

Hamalik dalam Arsyad (2014:19) mengemukakan bahwa pemakaian media pembelajaraan dalam proses pembelajaraan dapat menumbuhkan minat baru dan rangsangan proses pembelajaraan serta mampu membangkitkan motivasi peserta didik-peserta didik. Penggunaan media pembelajaraan pada proses pembelajaraan sangat membantu keefektifan dalam tujuan peningkatan pemahaman peserta didik. Pada zaman globalisasi dengan teknologi yang semakin maju, guru harus pandai dalam memanfaatkan alat-alat penunjang pembelajaraan seperti menggunakan media berbasis TPACK agar dalam kegiatan belajar mengajar dapat mampu membangkitkan kondisi belajar yang menarik dan membahagiakan.

Sementara itu, untuk menerapkan pembelajaran matematika yang baik dengan meningkatkan keaktifan peserta didik serta pemecahan masalah matematika menjadi proses penyelesaiannya. Pembelajaran pendekatan open ended menjadi solusi untuk kegiatan belajar matematika karena dengan diberikan permasalah soal oleh guru, peserta didik akan menjawab dengan jawaban sama pada hasil akhirnya tetapi guru harus lebih menekankan peserta didik untuk sampai pada cara bagaimana mencapai pada suatu jawaban.

Proses pembelajaran diharapkan mampu menerapkan kemampuan penalaran matematis peserta didik. Menurut Zubaidah (2016:31) mengatakan bahwa kemampuan penalaran matematis merupakan suatu kebiasaan otak seperti halnya kebiasaan lain yang harus dikembangkan secara konsisten menggunakan berbagai macam konteks, mengenal penalaran dan pembuktian merupakan aspek-aspek fundamental dalam matematika. Dengan penalaran matematis, peserta didik dapat mengajukan dugaan 
kemudian menyusun bukti dan melakukan manipulasi terhadap permasalahan matematika serta menarik kesimpulan dengan benar dan tepat.

Oleh karena itu, guru memiliki peranan dalam menumbuhkan kemampuan penalaran matematis dalam diri peserta didik baik dalam bentuk metode pembelajaran yang dipakai, maupun dalam evaluasi berupa pembuatan soal yang mendukung. Meningkatkan kemampuan penalaran matematis peserta didik perlu didukung oleh pendekatan pembelajaran yang tepat serta media pembelajaran yang menunjang sehingga tujuan pembelajaran dapat tercapai. Proses pembelajaran diharapkan mampu menerapkan kemampuan penalaran matematis peserta didik dengan menerapkan pendekatan open ended berbasis TPACK dengan tepat.

Berdasarkan uraian di atas rumusan penelitian ini yaitu: (1) Bagaimana konsep pendekatan open ended berbasis TPACK? (2) Bagaimana konsep penalaran matematis? (3) Bagaimana hubungan pendekatan open ended berbasis TPACK dengan penalaran matematis?

\section{HASIL DAN PEMBAHASAN}

\section{A. Konsep Pendekatan Open ended Berbasis TPACK}

Pendekatan open ended merupakan salah satu pendekatan dalam pembelajaran yang diterapkan oleh guru. Menurut Shimada (Arsad, 2013:5) model Open ended adalah suatu pendekatan pembelajaran yang dimulai dari mengenal atau menghadapkan peserta didik pada masalah terbuka. Pembelajaran dilanjutkan dengan menggunakan banyak jawaban yang benar dari masalah yang diberikan untuk memberikan pengalaman kepada peserta didik dalam menemukan sesuatu yang baru di dalam proses pembelajaran. Open ended adalah pembelajaran yang menyajikan suatu permasalahan yang memiliki metode atau penyelesaian yang benar lebih dari satu. Menurut Suherman (2010:123) problem yang diformulasikan memiliki multi jawaban yang benar disebut problem tak lengkap atau disebut juga Open ended problem atau soal terbuka.

Tujuan dari pembelajaran open ended menurut Nohda (Suherman, 2010:124) ialah untuk membantu mengembangkan kegiatan kreatif dan pola pikir matematik peserta didik melalui problem solving secara simultan. Dengan kata lain, kegiatan kreatif dan pola matematik peserta didik harus dikembangkan semaksimal mungkin sesuai dengan kemampuan setiap peserta didik. Hal yang dapat digaris bawahi adalah perlunya memberi kesempatan peserta didik untuk berpikir dengan bebas sesuai dengan minat dan kemampuannya. Aktivitas kelas yang penuh dengan ide-ide matematika ini pada gilirannya akan memacu kemampuan berpikir tinggi peserta didik.

Menurut Lestari, dkk (2016), langkah-langkah dalam pendekatan open ended ada 6 yaitu (1) orientasi; (2) penyajian masalah terbuka; (3) pengerjaan masalah terbuka secara individu; (4) diskusi kelompok tentang masalah terbuka; (5) Persentasi hasil diskusi kelompok; dan (6) penutup. Dalam tabel berikut disajikan langkahlangkah pendekatan Open ended

\section{Tabel 1. Langkah-langkah Open Ended}

\begin{tabular}{ll}
\hline \multicolumn{1}{c}{ Langkah Open Ended } & \multicolumn{1}{c}{ Kegiatan } \\
\hline Orientasi & Pembelajaran diawali dengan penyampaian \\
& tujuan pembelajaran dan pemberian motivasi \\
& kepada peserta didik berupa masalah yang \\
berkaitan dengan kehidupan sehari-hari.
\end{tabular}

Penyajian masalah terbuka Guru memberikan masalah secara umum tentang materi yang akan diberikan. 
Pengerjaan masalah terbuka secara individu

Diskusi kelompok tentang masalah terbuka

Persentasi hasil diskusi kelompok

Penutup
Peserta didik diminta mengerjakan soal atau menyelesaikan masalah secara individu. Hal ini bertujuan untuk mengetahui perkembangan tingkat kreativitas peserta didik secara individu akibat pembekalan yang diberikan kepada peserta didik. Pada saat peserta didik mengerjakan masalahnya atau soal yang diberikan tidak diperkenankan untuk minta bantuan kepada teman-temannya yang lain sehingga peserta didik benar-benar terpacu kreativitasnya untuk menyelesaikan masalahnya sendiri. Setelah selesai mengerjakan soal atau masalah, peserta didik diminta untuk mengumpulkan lembar penyelesaiannya.

Peserta didik diminta bekerja secara berkelompok untuk mendiskusikan penilaian dari masalah open-ended yang telah dikerjakan secara individu. Dengan demikian diharapkan diskusi kelompok akan dapat memunculkan ide pada tiap peserta didik sehingga nantinya kreativitas siwa akan meningkat.

Beberapa atau semua anggota kelompok mempresentasikan hasil kerja kelompok mereka.

Peserta didik bersama guru menyimpulkan atau membuat ringkasan singkat tentang konsep atau ide yang terdapat pada permasalahan yang diajukan

TPACK merupakan kerangka kerja/pendesain dalam mengintegrasikan TIK dalam pembelajaran. TPACK menekankan hubungan antara teknologi materi dan pedagogi yang berinteraksi satu sama lain untuk menghasilkan pelajaran berbasis TIK. TPACK merupakan pembelajaran yan g memanfaatkan teknologi yang hasilnya sangat baik untuk memahami konsep materi (Arsyad, 2014). Dalam kerangka kerja TPACK, materi pembelajaran dikemas dengan menggunakan model pembelajaran yang sesuai dengan karakteristiknya dan dipadukan dengan teknologi. Model pembelajaran merupakan kerangka konseptual yang melukiskan prosedur yang sistematis dalam mengorganisasikan pengalaman belajar untuk mencapai tujuan belajar.

Perlunya dikembangkan perangkat pembelajaran untuk meningkatkan kemampuan penalaran matematis. Perangkat pembelajaran yang terdiri dari RPP dan LKS pembelajaran disusun berdasarkan KD dan KI pada kurikulum 2013 dengan menggunakan pendekatan Open ended berbasis TPACK. Pendekatan TPACK merupakan pendekatan pembelajaran yang memadukan antara materi, pedagogi dan teknologi. Pendekatan TPACK dapat diintegrasikan dengan model yang dapat melatih peserta didik untuk menemukan pengetahuan baru secara mandiri namun tetap mendapat bimbingan guru. Salah satu model yang dapat digunakan yaitu model Open ended. Model pembelajaran Open ended yaitu suatu pendekatan pembelajaran yang dimulai dari mengenalkan atau menghadapkan peserta didik pada masalah terbuka. Pembelajaran dilanjutkan dengan menggunakan banyak jawaban yang benar dari masalah yang ada, sehingga memberikan pengalaman kepada peserta didik dalam menemukan sesuatu yang baru di dalam proses pembelajaran. 
Gusnidar, dkk (2018) hasil penelitian "Pengembangan perangkat pembelajaran matematika berdasarkan kerangka kerja TPACK untuk mengoptimalkan kemampuan penalaran deduktif" yang telah dilakukan maka dapat disimpulkan bahwa perangkat pembelajaran matematika kerangka kerja TPACK bahwa komponen Technology Content Knowledge (TCK) mempunyai pengaruh paling besar terhadap kemampuan penalaran deduktif. Saran yang harus dilakukan yaitu penguasaan pedagogi yang bervariasi, mampu merancang pembelajaran yang tidak hanya menitik beratkan pada hasil belajar, tetapi juga aktivitas belajar, dan keterampilan berpikir tingkat tinggi peserta didik.

Dari beberapa uraian diatas dapat disimpulkan bahwa pendekatan open ended adalah upaya yang dilakukan guru untuk memberikan kesempatan kepada peserta didik untuk memperoleh pengetahuan, pengalaman menemukan, menemukan dan memecahkan masalah dengan beberapa penyelesaian yang berbeda, serta menghargai keragaman berpikir yang mungkin timbul dalam mengerjakan soal. Pendekatan open ended dapat memberi kesempatan peserta didik untuk berpikir sesuai kemampuannya serta membangun interaktif antara matematika dengan peserta didik. Dan TPACK menekankan hubungan antara teknologi materi dan pedagogi yang berinteraksi satu sama lain untuk menghasilkan pelajaran berbasis TIK. Sehingga dengan menggunakan pendekatan Open ended berbasis TPACK dapat melatih kemampuan berpikir tingkat tinggi peserta didik dalam penalaran matematis.

\section{B. Konsep Penalaran Matematis}

Fachrudin (2012:37) mengemukakan penalaran memiliki pengertian yang berbeda-beda seperti yang dikemukaan oleh para ahli yaitu Jacob (2003) bahwa penalaran adalah: "bentuk khusus dari berpikir dalam upaya pengambilan penyimpulan konklusi yang dgambarkan premis (Copi, 1979), simpulan berbagai pengetahuan dan keyakinan mutakhir (Glass dan Holyoak, 1986), menstransformasikan informasi yang diberikan untuk menelaah konklusi (Galloti, 1989)". Menurut Suherman (2010) penalaran adalah proses berpikir yang dilakukan dengan suatu cara untuk menarik kesimpulan. Kesimpulan yang diperoleh dari hasil bernalar, didasarkan pada pengamatan datadata yang ada sebelumnya dan telah diuji kebenarannya.

Zubaidah (2016:78) menyatakan bahwa penalaran matematis merupakan suatu kebiasaan otak seperti halnya kebiasaan yang lain yang harus dikembangkan secara konsisten dengan menggunakan berbagai macam konteks.

Berkenaan dengan penalaran, Fachrudin (2012:45) mengemukakan National Council of Teacher of Mathematics (NCTM) bahwa dalam pelaksanaan pembelajaran matematika, guru harus memperhatikan lima kemampuan matematis yaitu: koneksi (connections), penalaran (reasoning), komunikasi (communications), pemecahan masalah (problem solving), dan representasi (representations). Oleh karena itu, guru memiliki peranan dalam menumbuhkan kemampuan penalaran matematis dalam diri peserta didik baik dalam bentuk metode pembelajaran yang dipakai, maupun dalam evaluasi berupa pembuatan soal yang mendukung. Meningkatkan kemampuan penalaran matematis peserta didik perlu didukung oleh pendekatan pembelajaran yang tepat sehingga tujuan pembelajaran dapat tercapai.

Berdasarkan uraian di atas dapat di simpulkan kemampuan penalaran matematis membantu peserta didik dalam menyimpulkan dan membuktikan suatu pernyataan, membangun gagasan baru, sampai pada menyelesaikan masalah-masalah dalam matematika. Oleh karena itu, kemampuan penalaran matematis harus selalu dibiasakan dan dikembangkan dalam setiap pembelajaran matematika. Pembiasaan tersebut harus dimulai dari kekonsistenan guru dalam mengajar terutama dalam pemberian soal-soal yang rutin. 


\section{Hubungan Pendekatan Open ended Berbasis TPACK Dengan Penalaran Matematis}

Penalaran dalam matematika memiliki peran yang amat penting dalam proses berfikir seseorang. Penalaran juga merupakan pondasi dalam pembelajaran matematika. Hal ini sejalan dengan tujaun dari pembelajaran matematika yakni bagaimana mengajarkan kepada peserta didik mengenai penalaran logika. Bila kemampuan bernalar pada peserta didik tidak dikembangkan maka bagi peserta didik matematika hanya akan menjadi materi yang serangkaian prosedur dan meniru contoh-contoh tanpa mengetahui maknanya. Dengan demikian kemampuan penalaran peserta didik dapat dikembangkan melalui pendekatan open ended. Dalam pendekatan open ended guru memberikan permasalahan kepada peserta didik yang solusinya tidak perlu ditentukan hanya melalui satu jalan. Guru harus memanfaatkan keragaman cara atau prosedur yang ditempuh peserta didik dalam memecahkan masalah. Hal tersebut akan memberikan pengalaman kepada peserta didik dalam menemukan sesuatu yang baru berdasarkan pengalaman, keterampilan dan cara berfikir matematik yang telah diperoleh sebelumnya.

Lestari, dkk (2016) mengemukakan ada beberapa keunggulan dari pendekatan open ended, antara lain: (1) Peserta didik memiliki kesempatan untuk berpartisipasi secara lebih aktif serta memungkinkan untuk mengekspresikan idenya; (2) Peserta didik memiliki kesempatan lebih banyak menerapkan pengetahuan serta ketrampilan matematika secara komprehensif; (3) Peserta didik dari kelompok lemah sekalipun tetap memiliki kesempatan untuk mengekspresikan penyelesaian masalah yang diberikan dengan cara mereka sendiri; (4) Peserta didik terdorong untuk membiasakan diri memberikan bukti atas jawaban yang mereka berikan; (5) Peserta didik memiliki banyak pengalaman, baik melalui temuan mereka sendiri maupun dari temannya dalam menjawab permasalahan.

Guru memiliki peranan dalam menumbuhkan kemampuan penalaran matematis dalam diri peserta didik dengan menggunakan pendekatan open ended. Proses pembelajaran diharapkan mampu menumbuhkan kemampuan penalaran matematis peserta didik dengan menerapkan pendekatan open ended berbasis TPACK dengan tepat. Pendekatan open ended berbasis TPACK disini pendekatan yang dilakukan adalah dengan menggunakan media yang berbasis TIK.

Menurut Lestari, dkk (2016) ada keterkaitan hubungan antara pendekatan open ended dengan penalaran matematis. Adapun keterkaitan open ended dan penalaran dapat dilihat pada tabel berikut:

Tabel 2. Keterkaitan Open ended dan Penalaran Matematis

\begin{tabular}{ll}
\multicolumn{1}{c}{ Pendekatan Open ended } & \multicolumn{1}{c}{ Penalaran Matematis } \\
\hline $\begin{array}{l}\text { Proses terbuka (Process is } \\
\text { open) }\end{array}$ & $\begin{array}{l}\text { Mengajukan dugaan } \\
\text { Melakukan manipulasi matematika }\end{array}$ \\
$\begin{array}{l}\text { Hasil akhir tebuka (End } \\
\text { product are open) }\end{array}$ & $\begin{array}{l}\text { Menarik kesimpulan dari pernyataan } \\
\text { Memeriksa kesahihan suatu pernyataan }\end{array}$ \\
$\begin{array}{ll}\text { Cara pengembangan terbuka } \\
\text { (Ways to develop are open) }\end{array}$ & $\begin{array}{l}\text { Menyusun bukti, memberikan alasan atau bukti } \\
\text { terhadap kebenaran suatu solusi } \\
\text { Menemukan pola atau sifat dari gejala matematik } \\
\text { untuk membuat generalisasi }\end{array}$ \\
\end{tabular}

Dengan adanya hubungan yang erat antara pendekatan open ended dengan penalaran matematis, maka kegiatan pendekatan open ended dikembangkan dengan berbasis TPACK, dimana kegiatannya dilakukan dengan berbasis media yang berhubungan dengan TIK. Diharapkan dengan pendekatan open ended berbasis 
TPACK yang menggunakan teknologi masa sekarang akan lebih mampu dan lebih baik dalam menanamkan penalaran matematis.

Dari uraian di atas dapat disimpulkan bahwa pendekatan open ended merupakan inovasi dalam pembelajaran yang dirancang dan dikembangkan untuk mengembangkan kemampuan bernalar peserta didik dalam memecahkan masalah, karena dalam pendekatan open ended kemampuan bernalar peserta didik dapat dioptimalisasikan melalu kerja kelompok atau tim sehingga peserta didik dapat mengembangkan kemampuan bernalarnya secara berkesinambungan. Apalagi pendekatan yang dilakukan dikembangkan lagi dengan berbasis TPACK yang pastinya menyenangkan dan tidak membosankan dalam pembelajaran matematika. Sehingga penerapan pendekatan open ended berbasis TPACK dapat memberi pengaruh terhadap kemampuan peserta didik dalam penalaran matematis.

\section{SIMPULAN}

Sesuai dengan rumusan masalah dan pembahasan, dapat diambil simpulan bahwa (1) Pendekatan Open ended berbasis TPACK adalah pembelajaran yang menyajikan suatu permasalahan yang memiliki metode atau penyelesaian yang benar lebih dari satu, yang disajikan dengan berbantuan media yang berbasis TIK. (2) Penalaran matematis adalah kemampuan menyimpulkan dan membuktikan suatu pernyataan, membangun gagasan baru, sampai pada menyelesaikan masalahmasalah dalam matematika. (3) Penalaran matematis dapat ditanamkan pada peserta didik melalui pendekatan open ended berbasis TPACK.

\section{DAFTAR PUSTAKA}

Anas, S. (2016). Pengantar Evaluasi Pendidikan. Jakarta: Raja Grafindo.

Anggarayanthi, L. A., Suniasih, N. W., \& Suara, I. M. (2016). Penerapan Model Discovery Learning Berbantuan Media Llingkungan untuk Meningkatkan Hasil Belajar IPA Tema Ekosistem Peserta didik Kelas VA SD N 12 Padang Sambian. e-Journal Universitas Pendidikan Ganesha, 4 (1), 2. Diunduh dari Anugraheni, I. (2017).

Arsad HS, Dwi NS, Winanda Marito. 2013. Pendekatan Open ended Problem. Diambil dari http//www.academia.edu. Diakses tanggal 28 Mei 2021.

Arsyad, Azhar. 2014. Media Pembelajaran. Jakarta: Raja Grafindo Persada.

Fachrudin, A. D. (2012). Alternatif Pembelajaran Pemecahan Masalah dan Langkah Pemecahannya. Jakarta: Rineka Cipta.

Gusnidar, dkk. 2018. Pengembangan Perangkat Pembelajaran Matematika Berdasarkan Kerangka Kerja TPACK Untuk Mengoptimalkan Kemampuan Penalaran Deduktif. Jambi: Unversitas Jambi.

Hasibuan, Jose. 2020. Pendekatan TPACK dalam Pembelajaran Abad 21. www.kompasiana.com. Diakses tanggal 28 Mei 2021.

Lestari,Neny,dkk. 2016. Pengaruh Pendekatan Open-Ended Terhadap Penalaran Matematika Peserta didik. Jurnal Pendidikan Matematika Volume 10 No.1. Retrieved from https:// https://ejournal.unsri.ac.id/media/publications/122911-IDpengaruh-pendekatan-open-ended-terhadap.pdf.

Suherman, Erman dkk. 2010. Strategi Pembelajaran Matematik Kontemporer. Bandung. Universitas Pendidikan Indonesia.

Zubaidah, Amir dan Risnawati. (2016). Psikologi Pembelajaran Matematika. Yogyakarta: Aswaja Pressindo. 